\title{
EFFECT OF WATER LEVEL AND CLIMATIC FACTORS ON THE RADIAL GROWTH OF BLACK ALDER
}

\author{
Didzis Elferts, lluta Dauškane, Guna Ūsele, and Agita Treimane
}

Faculty of Biology, University of Latvia, Kronvalda bulv. 4, Rīga LV-1586, LATVIA

E-mail: didzis.elferts@lu.Iv

Communicated by Māris Kḷaviṇš

\begin{abstract}
Black alder (Alnus glutinosa (L.) Gaertn.) is a widespread tree species in Europe and the western part of the temperate climate zone. The area of forest in Latvia dominated by this tree species has substantially decreased due to wide-spread forest drainage. To predict future changes due to environmental change, it is extremely important to understand the function of ecosystems with black alder and their dynamics. Tree rings can be used as a proxy of past environmental factors. The aim of the study was to determine the effects of meteorological and hydrological factors on radial growth of black alder at two study sites (Dursupe and Rakupe) in Latvia. The response of black alder trees to the influence of climatic and hydrological factors was found to depend on site conditions, i.e. a climatic effect was observed in conditions when the water level was low. Spatial variation in the strength of the relationship of black alder growth to temperature, precipitation, and river level suggests that alder growth is more susceptible to drought stress on higher river banks, where the water table is deeper. Black alder trees growing on low river banks can potentially be used to reconstruct past water-levels.
\end{abstract}

Key words: black alder, tree rings, river water level, dendroclimatology.

\section{INTRODUCTION}

Tree-ring width can be used as a proxy of environmental factors, such as climate condition, soil fertility, insect outbreaks and competition (Schweingruber, 1996; Laganis et al., 2008; Rodríguez-González et al., 2010). Both drought and water availability can be limiting factors for tree growth. In wetlands, a high water level and water saturation can be chronic stressors for trees. Seasonal and permanent flooding affects individual trees, stand composition, structure and growth, as well as the whole ecosystem (Mitsch and Gosselink, 2007; Rodríguez-González et al., 2010) Therefore, tree-ring width can be successfully used for reconstructions of past water level or streamflow (Case and MacDonald, 2003; Lara et al., 2005).

Black alder (Alnus glutinosa (L.) Gaertn.) is a common deciduous species in mesic wet sites (Eschenbach and Kappen, 1999) and is well able to grow in areas that are periodically flooded (Bair and Hennessey, 1982). Adaptations of alder for living in a habitat with a high water level include roots located close to soil surface and a deep taproot (McVean, 1953; McVean, 1956). Another advantage for growth in wet habitats is a high transpiration potential (Priedītis, 1997; Schrader et al., 2005). Black alder is light demanding, capable of fast growth and has a short life-time. Significant height growth usually stops at about 60 years (Evans, 1984; Laganis et al., 2008). This deciduous tree species is less dependent on soil nitrogen, as Alnus sp. can fix $\mathrm{N}_{2}$ in the roots through symbiosis with the actinomycete Frankia (Laganis et al., 2008; Rodríguez-González et al., 2010). However, during flooding the oxygen level in soil decreases, which can have a negative impact on nitrogen fixation (McVean, 1956; Virtanen, 1957; Griffiths, McCormick, 1984; Kaelke and Dawson, 1997).

There are no available studies on the effect of climate and hydrology on tree ring growth of black alder. This type of information is necessary to understand the ecology of this deciduous species, and to predict effect of global climate change.

We hypothesised that tree-rings of black alder growing near the rivers would be a suitable proxy of river water level. The purpose of this study was to determine the relationships of meteorological and hydrological factors on the radial growth of black alder.

\section{MATERIALS AND METHODS}

Sampling site. Two sampling sites were established on the banks of small rivers Dursupe and Raķupe near hydrological stations where monitoring data on water level was available (Fig. 1). At both sampling sites black alder trees were located near the river. The Rakupe sampling site (X: 395059, Y: 6361318) was characterised by a very low 


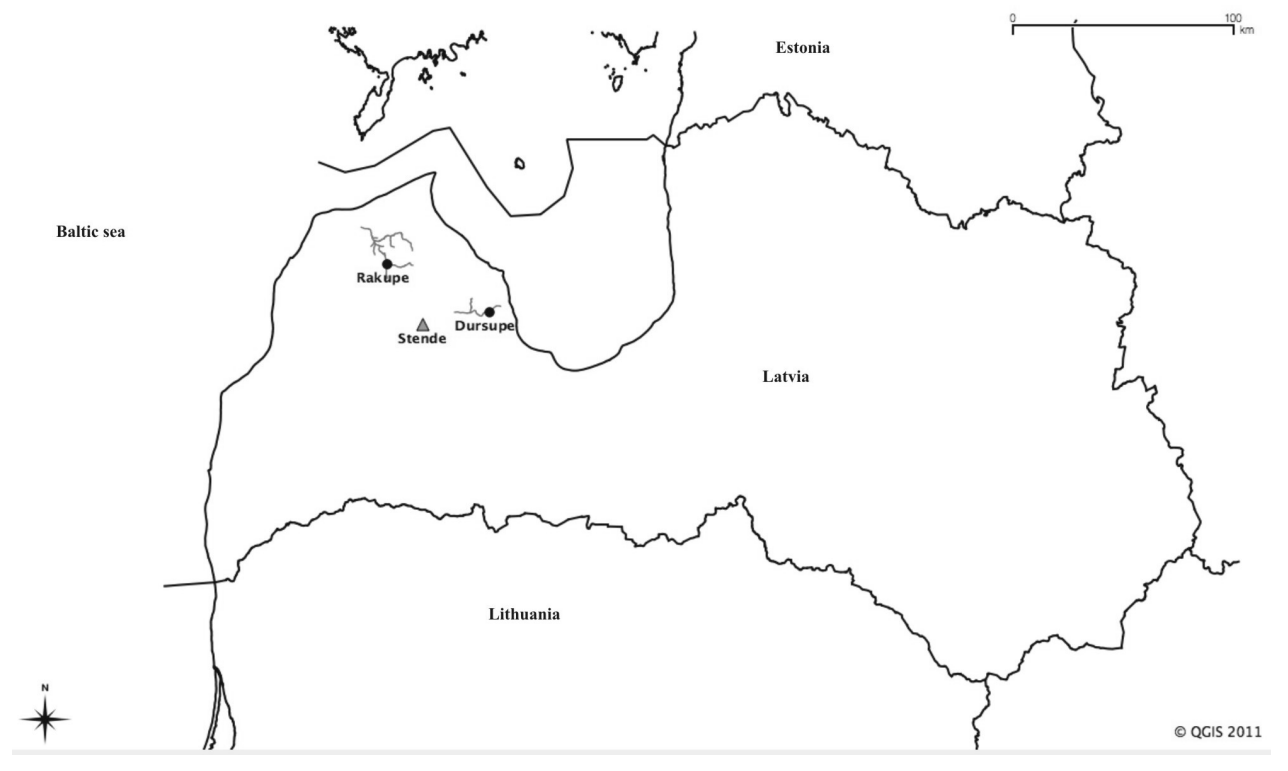

Fig. 1. Location of Dursupe un Raķupe sampling sites (circle) and Stende meteorological station (triangle). height of the bank above the water level. The difference between water level and top of the river bank in October was only $15-20 \mathrm{~cm}$, indicating that flooding occurs during high water level periods in spring. At the Dursupe sampling site (X: 441057, Y: 6339773), the river banks were much higher - the height of the river bank above the water level was more than $100 \mathrm{~cm}$ in October.

Meteorological and hydrological data. Meteorological data for the Stende meteorological station were obtained from the Latvian Environment, Geology and Meteorology Centre. Data on mean monthly temperature and precipitation amount for the previous and current year were used. Hydrological data (mean, maximal and minimal monthly water level) for the rivers Dursupe un Raķupe were obtained from "Meliorprojekts" Ltd. The water-level data were available for the time period 1963-2005 (Fig. 2).

Meteorological and hydrological data were also aggregated into autumn (previous year September - November), winter (previous year December - current year February), spring (March - May), summer (June - August) and season (previous year October - current year September) periods.

Sample collection, preparation and measurement. Cores from black alder were collected in 2008 for the Raķupe plot and in 2008 and 2010 in the Dursupe plot. Plot size was 3 meters wide and 20 meters long. Using an increment borer two cores from opposite sides of each tree were taken at breast high. A total of 18 trees growing close to river at Raķupe and 17 trees at Dursupe were sampled. The cores were dried and gradually sandpapered (from 80 till 500 grade). LINTAB tree ring width measuring equipment and TSAPWin software were used for tree-ring width measurement (Rinn, 1996). All tree-ring series from each site were checked using a combination of visual, graphical, and statistical cross-dating techniques. Visual and graphical techniques were used to correct misdated samples. Dating accuracy was checked with COFECHA software (Holmes, 1983). After tree-ring width measurement and quality control, mean tree-ring width was calculated for each tree that had two cross-dated cores.

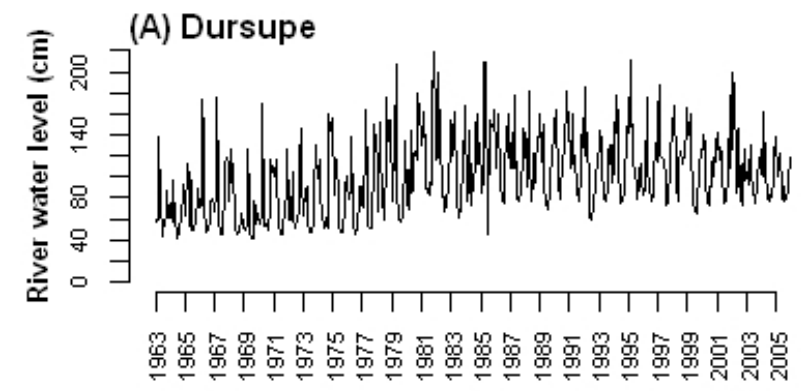

Year

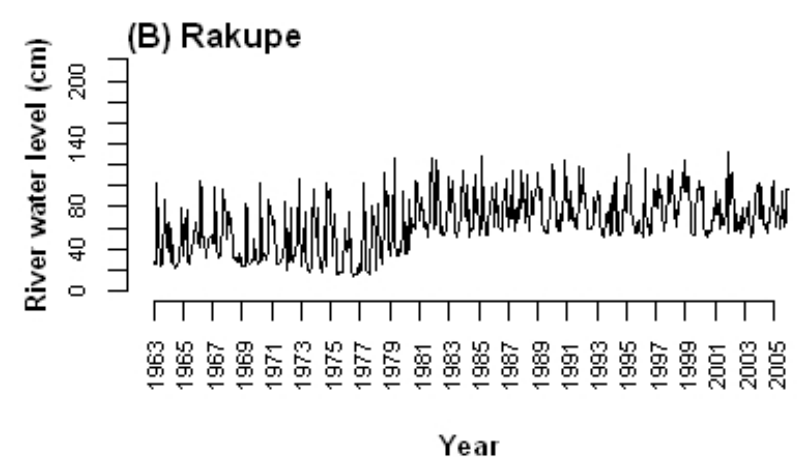

Fig. 2. Mean monthly river water level for the Dursupe (A) un Raķupe (B) rivers for 1963-2005.

\section{Statistical analysis}

For each sampling plot tree-ring width series were detrended on a modified negative exponential curve using the package dplR (Bunn, 2008) in program R (Anonymous 2011). These were then combined to build a residual chronology after applying auto-regressive modelling (Holmes, 1999). EPS (expressed population signal) values for both sampling sites were calculated to determine whether chronologies showed a common signal for the site (EPS value higher than 0.85 ) or if signals of individual trees dominate 
in the chronology (EPS value lower than 0.85) (Speer, 2010).

Pointer-year intensity values for each sampling site were calculated by the modified Skeleton-plot method. Intensity values were defined as extreme positive or negative deviations from the average tree-ring width in a single tree-ring series. Tree-ring width of each year of a tree was compared to the mean tree-ring width of the previous five years. According to the intensity of a single growth deviation, five intensity classes were used. The 5th intensity class, which was the maximum intensity class, was defined as a tree ring that was at least $80 \%$ narrower or wider than the mean of the neighbouring rings, and the 1 st intensity class was when the difference was less than 20\% (Neuwirth et al., 2004; Elferts, 2007). Site pointer year intensity $(I)$ was calculated using the formula:

$I=\frac{100}{k \cdot n} \sum_{j=1}^{k} h_{j} \cdot i_{j}(\%)$

where $k$ - number of intensity class; $n$ - total number of trees; $h_{j}$ - number of trees in intensity class; $i_{j}$ - value of intensity class.

Pearson correlation coefficients between chronologies and meteorological/hydrological data, as well as between pointer-year intensity values and meteorological/hydrological data were determined.

\section{RESULTS}

After tree-ring measurement and crossdating, 14 tree-ring series for Raķupe and Dursupe sampling sites were used for further analysis. EPS values were 0.925 (Raķupe) and 0.887 (Dursupe). The Dursupe chronology had a length of 71 years and the Raķupe chronology -44 years (Fig. 3).

In the period 1970-2008 (common period for both sampling sites), 17 pointer-years for Dursupe, and 18 for Raķupe with the intensity values lower than -25 or higher than 25 were identified (Fig. 4). Of those pointer-years, ten were common for both sampling sites: negative pointer-years 1979, 1981, 1985, 1994, 1999 and 2004; positive pointeryears 1983, 1988, 1992 and 2007.

For the Dursupe plot there was no statistically significant correlation between water level and pointer-year value. A significant correlation was found for this plot between previous year maximal May water level (positive), as well as current year minimal May water level (negative), and tree-ring index (Table 1). For the Raķupe plot, tree-ring index was significantly negatively related to previous year (August-December) maximal and mean (September, October) water level, but no correlation was found for current year water level. Mean water level at Raķupe was positive correlated with pointer-year value for previous year April and May.

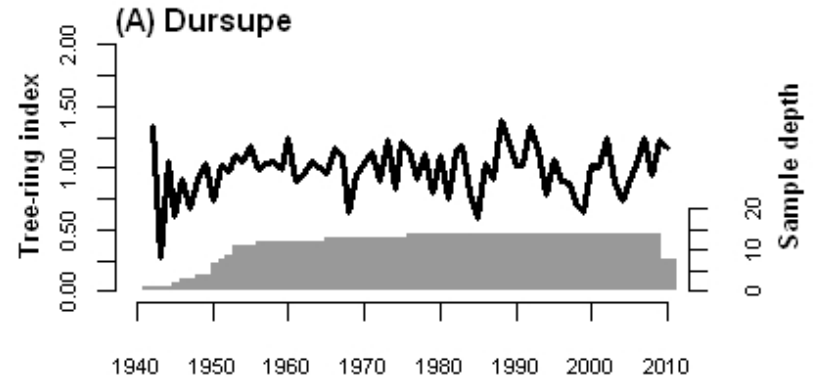

Year

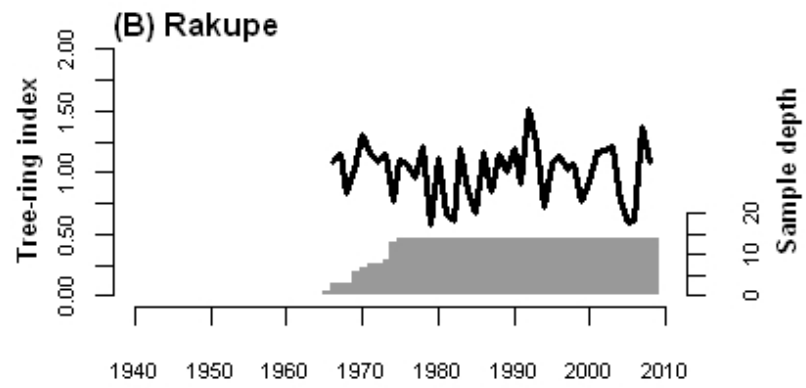

Year

Fig. 3. Residual chronologies and sampling depth for the (A) Dursupe and (B) Raķupe sampling plots.
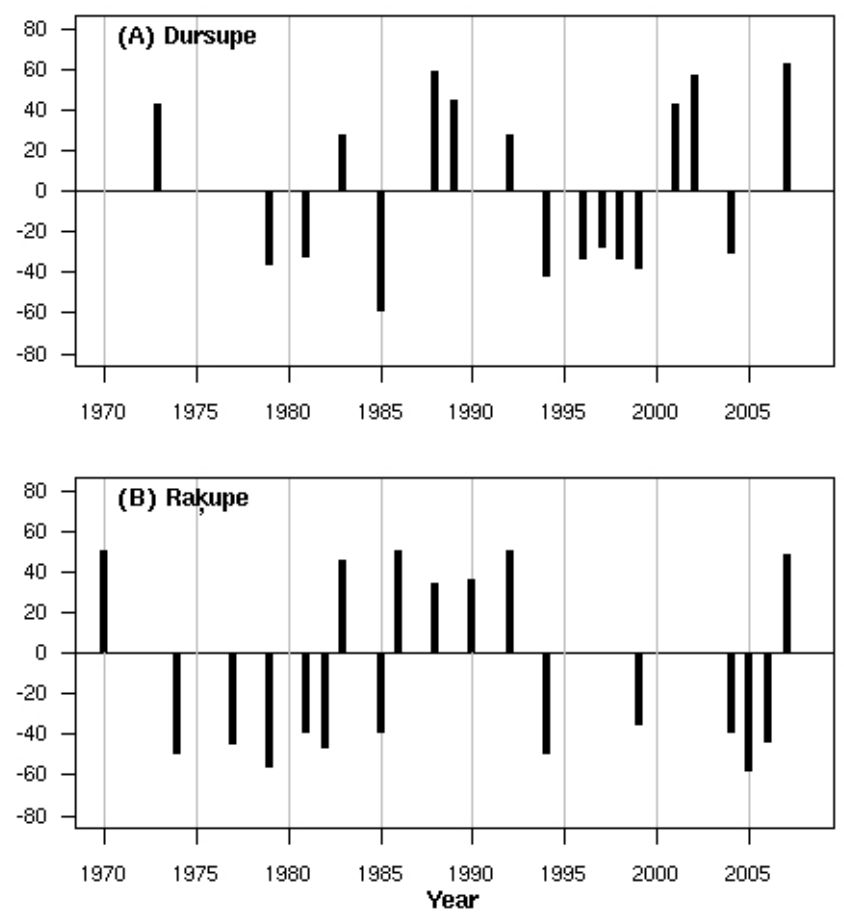

Fig. 4. Pointer-year intensity values (higher than 25 or lower than -25) for the (A) Dursupe and (B) Raķupe sampling plots.

Only four precipitation amount parameters had a significant correlation with tree-ring index or pointer-year value, but these differed between the plots. Dursupe pointer-year in- 
Table 1

SIGNIFICANT CORRELATION COEFFICIENTS $(P=0.05)$ BETWEEN TREE-RING INDEX OF DURSUPE, RAKUPE RESIDUAL CHRONOLOGIES AND POINTER-YEAR INTENSITY VALUE AND CLIMATOLOGICAL (PRECIPITATION AMOUNT AND MEAN TEMPERATURE) AND HYDROLOGICAL (MEAN, MAXIMAL AND MINIMAL WATER LEVEL) FACTORS

\begin{tabular}{|c|c|c|c|c|}
\hline \multirow[t]{2}{*}{ Factor } & \multicolumn{2}{|c|}{ Chronology } & \multicolumn{2}{|c|}{ Pointer-years } \\
\hline & Dursupe & Rakupe & Dursupe & Rakupe \\
\hline \multicolumn{5}{|c|}{ Previous year maximal water level } \\
\hline May & 0.306 & & & \\
\hline August & \multicolumn{3}{|c|}{-0.329} & \\
\hline September & \multicolumn{3}{|c|}{-0.395} & \\
\hline October & \multicolumn{3}{|c|}{-0.375} & \\
\hline December & \multicolumn{3}{|c|}{-0.338} & \\
\hline \multicolumn{5}{|c|}{ Previous year mean water level } \\
\hline April & & & & 0.336 \\
\hline May & & & & 0.371 \\
\hline September & \multicolumn{3}{|c|}{-0.324} & \\
\hline October & \multicolumn{3}{|c|}{-0.400} & \\
\hline \multicolumn{5}{|c|}{ Minimal water level } \\
\hline May & \multicolumn{2}{|l|}{-0.310} & & \\
\hline \multicolumn{5}{|c|}{ Previous year precipitation amount } \\
\hline April & \multicolumn{3}{|c|}{0.316} & \\
\hline November & & & 0.307 & \\
\hline \multicolumn{5}{|c|}{ Precipitation amount } \\
\hline January & \multicolumn{3}{|c|}{0.352} & 0.454 \\
\hline June & -0.306 & & -0.303 & \\
\hline \multicolumn{5}{|c|}{ Previous year mean temperature } \\
\hline May & -0.345 & & & \\
\hline August & \multicolumn{3}{|c|}{0.336} & \\
\hline \multicolumn{5}{|c|}{ Mean temperature } \\
\hline January & & & 0.301 & \\
\hline February & & & 0.341 & \\
\hline May & & & 0.344 & \\
\hline July & 0.315 & & 0.343 & \\
\hline Autumn & & & & 0.372 \\
\hline Winter & & & 0.368 & \\
\hline Season & & 0.365 & 0.417 & \\
\hline
\end{tabular}

tensity values had significant correlation with six current year mean temperature parameters, but Raķupe pointer-year value only with one. All were positive and showed no differences between seasons.

The only common climatic factor among the two sampling plots was season mean temperature, which showed a significant correlation with the tree-ring index at Rakipe and pointer-year value at Dursupe.

\section{DISCUSSION}

Trees in the Rakupe plot were much younger than in the Dursupe plot. This difference might be explained by different site history and management. Another reason might be different growth condition, since black alder usually reaches an older age on relative dryer soil than on wet soils with a peat layer (McVean, 1956; Prieditis, 1997), as in the Raķupe sampling site.

Increased water level can have negative effect on growth of black alder (McVean, 1956; Griffiths and McCormick, 1984; Kaelke and Dawson, 1997) as observed by negative correlation between maximal water level in autumn and December and tree growth in the Rakiupe plot. Black alders are still actively growing and allocating resources in August for the next year of growth and possibly also in September (Hall, Maynard, 1979). Maximum nitrogen fixation in black alder plants occurs in August (Stewart, 1962; Akkermans et al., 1976), and extreme water level in this month can influence nitrogen assimilation (Pizelle, 1984; Kozlowski, 1997). It is known that flooding during the growing season has greater effect than during the dormant season because it can cause injury, inhibition of growth (Kozlowski, 1997). The correlation between water level of previous year October/December and tree ring width may be explained by root activity. It has been reported (Kozlowski, 1997) that growth of roots continues in October and throughout the winter, except when the ground is frozen. Flooding decreases oxygen concentration, which in turn limits nutrient availability and gas exchange for plants, e.g., delays tree root respiration and therefore water uptake. The decreased nutrient uptake leads to decreased storage available for growth in the next year. For the Dursupe site, only current year May water level had a direct negative influence on growth, due to the reasons mentioned earlier. However at the Raķupe plot site, a high water level in previous year April and May had positive effect on pointer-years. A high water level in AprilMay can occur in years when spring begins early and when a substantial snow cover has accumulated, preventing freezing of the soil.

Although it has been reported that sudden and extreme water level changes can substantially influence nitrogen fixation (Pizelle, 1984; Kozlowski, 1997) and decrease also photosynthesis and growth, we found a poor relation between water level and pointer-year intensity values in the two sampling sites.

Although yearly water level fluctuation was more pronounced in Dursupe then Rakkupe (Fig. 2), the response to water level changes did not showed the same pattern. Both rivers showed an increase in mean water level after 1975, but it was not possible to determine if this change had a significant impact on the black alder growth, due to insufficient length of the water level and tree-ring series.

Pointer years were calculated to define years directly related to climate impact. At Dursupe, pointer-year intensity value was positively related to January, February and winter mean air temperature. In Latvia February is the coldest month of the year and has the lowest precipitation sum. A moderate temperature during this month can protect the black alder root system from freezing, especially in years when the snow cover is not deep. For example, a high negative pointer-year intensity value occurred in 1985 , which was the second coldest February recorded in Latvia. In this year 
there was also a very deep snow cover at March. Deep snow can affect ground water level during the growth period, which has significant effect on tree cambium activity and therefore also on vegetative and reproductive growth and development, as well as storage of nutrients for the next year. The soil becomes saturated, decreasing oxygen concentration, which in turn delays tree root respiration and water uptake, causing physiological drought (Kozlowski, 1997). At the Rakupe site, pointer-year intensity value was positively related to January precipitation amount and as in the Dursupe site this might be related with snow cover protecting roots.

Maximum precipitation in Latvia occurs in July and August, and there is a relatively high level of precipitation also in June. This has significant effect on seasonal ground water level. Air temperature during these months can have a direct effect on growth, or an indirect effect via evapotranspiration, affecting the hydrologic regime, and perhaps resulting in less moisture availability. For example, the negative pointer-year intensity value in 1979 was likely due to a very cold July, as this was a record low. In the other direction, the positive pointer-year intensity value in 2006 occurred when temperature in July reached an absolute maximum.

At the Dursupe site, pointer-year intensity value was positively related to previous year November precipitation amount, which might be explained by fact that usually higher November precipitation amount is related also with positive temperatures and a prolonged period for root activity.

Pointer-years did no show stable relation with temperature for the Rakupe site, as was observed for the Dursupe site. Pointer-year intensity value was positively correlated only with autumn mean temperature, which can be explained by an effect on photosynthesis and therefore on tree storage of nutrients for the next year (Kozlowski, 1997).

The sensitivity of growth of other alder species to inter-annual variation in hydrology varies across the landscape in relationship to river bank height and, therefore, depth to water table (Nossov et al., 2010). Thus, the response of black alder trees to influence of climatic and hydrological factors likely depends on site conditions, i.e. influence of climatic factor may occur only when the water level is low. As shown in our study, the spatial variation in the strength of the relationship of black alder growth to temperature, precipitation, and river level suggests that alder growth is more susceptible to drought stress on higher river banks, where the water table is deeper. The strong relationship between alder growth and river level on a low river bank suggests that alder growth is moisture-limited in these sites. Different response to water level between at least partly submerged trees and those growing farther from water has been observed also for other tree species (Begin, 2000). In conclusion, black alder trees can be used as a proxy for water-level reconstruction, in conditions when they are growing on low river banks.

\section{ACKNOWLEDGEMENTS}

The authors would like to thank Guntis Brūmelis for reviewing the language of the paper, Latvian Environment, Geology and Meteorology Centre for providing climatological data and State limited liability company "Meliorprojekts" for providing hydrological data. This study was performed with financial support of Latvian Council of Science (project No. 10.0004.5 "Analyses of ecological changes of the modelregion by the dendrochronological data").

\section{REFERENCES}

Anonymous (2011). $R$ : A language and environment for statistical computing. R Development Core Team. Vienna: R Foundation for Statistical Computing. http://www.R-project.org/

Akkermans, A.D.L., van Dijk, C. (1976). The formation and nitrogen-fixing activity of the root nodules of Alnus glutinosa under field conditions. In: Symbiotic Nitrogen Fixation in Plants (pp. 511-520). Nutman, P.S. (ed.). Cambridge: Cambridge University Press.

Bair, L.K., Hennessey, T.C. (1982). Variation in moisture stress tolerance for three Alnus species. In: Proceedings Seventh North American Forest Biology Workshop, Lexington, Kentucky, July 26-28 (pp. 446-449). Lexington: University of Kentucky.

Begin, Y. (2000). Reconstruction of subarctic lake levels over past centuries using tree rings. J. Cold Reg. Eng., 14, 192-212.

Bunn, A.G. (2008). A Dendrochronology Program Library in R (dplR). Dendrochronolgia, 26, 115-124.

Case, R.A., MacDonald, G.M. (2003). Tree ring reconstruction of streamflow for the three Canadian prairie rivers. J. Amer. Water Res. Assoc., 39, 703-716.

Elferts, D. (2007). Scots pine pointer-years in northwestern Latvia and their relationship with climatic factors. Acta Univ. Latv., 723, 163-170.

Eschenbach, Ch., Kappen, L. (1999). Leaf water relations of black alder (Alnus glutinosa (L.) Gaertn.) growing at neighbouring sites with different water regimes. Trees, 14, 28-38.

Evans, J. (1984). Silviculture of broadleaved woodland. Forest Com. Bull. (London), 62, 187-191.

Griffiths, A.P., McCormick, L.H. (1984). Effects of soil acidity on nodulation of Alnus glutinosa and viability of Frankia. Plant and Soil, 79, 429-434.

Hall, R.B., Maynard, C.A. (1979). Considerations in the genetic improvement of alder. In: Symbiotic nitrogen fixation in the management of temperate forests (pp. 322-344). Gordon, J.C. et al. (ed.). Corvallis: Oregon State University.

Holmes, R.L. (1983). Computer-assisted quality control in tree-ring dating and measurement. Tree-Ring Bull., 43, 69-78.

Holmes, R.L. (1999). Dendrochronology Program Library (DPL). Users Manual. Tucson, Arizona: University of Arizona.

Kaelke, C.M., Dawson, J.O. (1997). Seasonal flooding regimes influence survival, nitrogen fixation, and the partitioning of nitrogen and biomass in Alnus incana spp. Rugosa. Trees, 12, 27-34.

Kozlowski, T.T. (1997). Responses of woody plants to flooding and salinity. Tree Physiol. Monogr., 1, 1-29.

Lara, A., Urrutia, R., Villalba, R., Luckman, B.H., Soto, D., Aravena, J.C., Phee, J.M., Wolodarsky, A., Pezoa, L., León, J. (2005). The potential use of tree-rings to reconstruct streamflow and estuarine salinity in the Valdivian Rainforest eco-region, Chile. Dendrochronologia, 22, 155-161.

Laganis, J., Pečkov, A., Debeljak, M. (2008). Modeling radial growth increment of black alder (Alnus glutionsa (L.) Gaertn.) tree. Ecol. Model., 215, 180-189.

McVean, D.N. (1953). Biological flora of the British Isles: Alnus glutinosa (L.) Gaertn. (A. rotundifolia Stokes). J. Ecol., 41, 447-466. 
McVean, D.N. (1956). Ecology of Alnus glutinosa (L.) Gaertn. IV. Root system. J. Ecol., 44, 219-255.

Mitsch, W.J., Gosselink, J.G. (2007). Wetlands. Hoboken, New Jersey: John Wiley and Sons. $582 \mathrm{pp}$.

Neuwirth, B., Esper, J., Schweingruber, F.H., Winiger, M. (2004). Site ecological differences to the climatic forcing of spruce pointer years from the Lötschental, Switzerland. Dendrochronologia, 21, 69-78.

Nossov, D.R., Ruess, R.W., Hollingsworth, T.N. (2010). Climate sensitivity of thinleaf alder growth on an interior Alaskan floodplain. Ecoscience, 17, 312-320.

Pizelle, G. (1984). Seasonal variations of the sexual reproductive growth and nitrogenase activity W2112 in mature Alnus glutinosa. Plant Soil, 78, 181-188.

Priedītis, N. (1997). Alnus glutinosa-dominated wetland forests of the Baltic Region community structure, syntaxanomy and conservation. Plant Ecol., 129, 49-94.

Received 9 November 2011
Rinn, F. (1996). TSAP: Reference Manual. Heidelberg: Frank Rinn. 264 pp.

Rodríguez-González, P.M., Stella, J.Ch., Compelo, F., Ferreira, M.T., Albuquerque, A. (2010). Subsidy or stress? Tree structure and growth in wetland forests along a hydrological gradient in Southern Europe. Forest Ecol. Manag., 259, 2015-2025.

Schrader, J.A., Gardner, S.J., Graves, W.R. (2005). Resistance to water stress of Alnus maritima: Intraspecific variation and comparisons to other alders. Environ. Exper. Bot., 53, 281-298.

Schweingruber, F.H. (1996). Tree Rings and Environment: Dendroecology. Berne, Stuttgart, Vienna. 609 pp.

Speer, J.H. (2010). Fundamentals of Tree-ring Research. Tucson: The University of Arizona Press. 333 pp.

Stewart, W.D.P. (1962). A quantitative study of fixation and transfer of nitrogen in Alnus. J. Exper. Bot., 13, 250-256.

Virtanen, A. (1957). Investigations on nitrogen fixation by the alder. II. Associated culture of spruce and inoculated alder without combined nitrogen. Physiol. Plant., 10, 164-169.

\section{ŪDENS LĪMEN̦A UN KLIMATISKO FAKTORU IETEKME UZ MELNALKŠN̦A RADIĀLO AUGŠANU}

Melnalksnis (Alnus glutinosa (L.) Gaertn.) ir plaši izplatīta koku suga Eiropā un mērenās klimata zonas rietumu daḷā. Latvijā melnalkšņu mežu daudzums ir ievērojami krities sakarā ar mežu nosusināšanu. Lai prognozētu nākotnes izmaiņas saistībā ar vides izmaiņām, ir l,oti svarīgi saprast ekosistēmu ar melnalksni funkcionēšanu un dinamiku. Koku gadskārtas var izmantot kā informācijas avotu par pagātnes vides faktoriem. Šì pētījuma mērķis bija noskaidrot meteoroloǵisko un hidroloǵisko faktoru ietekmi uz melnalkšņa radiālo augšanu divās teritorijās Latvijāa (Dursupe un Raķupe). Tika noskaidrots, ka melnalkšņa atbilde uz klimatisko un hidroloǵisko faktoru ietekmi ir atkarīga no vietas apstākḷiem, tas ir, klimata ietekmes efekts novērojams apstākḷos, kad ūdens līmenis bija zems. Sakarības starp melnalkšna augšanu un temperatūru, nokrišñiem un ūdens līmeni telpiskā variācija norāda, ka melnalkšṇa augšana ir vairāk pakḷauta sausuma ietekmei uz augstākiem upju krastiem, kur ūdens līmenis ir zemāks. Melnalkšņi, kas auga uz zemiem upju krastiem, potenciāli var būt izmantojami ūdens līmeṇu rekonstrukcijai par senākiem laika periodiem. 